\title{
MAGNETOESTRATIGRAFIA DA CROSTA OCEÂNICA ENTRE AS ZONAS DE FRATURA DE ASCENSÃO E BODE VERDE
}

\author{
S. L. M. Mello ${ }^{1} \&$ M. S. Dias ${ }^{2}$
}

Foi desenvolvida uma análise sistemática das anomalias magnéticas marinhas, ao longo das Zonas de Fratura de Ascensão c Bode Verde, a fim de se estabelecer a magnetoestratigrafia detalhada da Placa Sul-Americana entre a Cordilheira Mesoatlântica c os estados da Bahia c Pernambuco. Este estudo possibilitou o mapcamento das anomalias magnéticas de expansão occânica c a obtenção de uma taxa de expansão occânica média de $2,3 \mathrm{~cm} /$ ano, para o período de 0 a $80 \mathrm{~m}$.a.. Reconheccu-se também períodos de cxpansão occânica com taxas relativamente clevadas $(3,3 \mathrm{~cm} / \mathrm{ano})$, que foram correlacionados a mudanças na direção das zonas de fraturas c à ocorrência de magmatismo na bacia oceânica c no bordo continental cmerso. Evidenciou-sc ainda uma notável correlação entre o aumento dos deslocamentos da porção transformante das zonas de fraturas c as variações nas taxas de expansão oceânica da região. De mancira geral um aumento no deslocamento correspondc a uma aceleração na taxa de cxpansão.Por fìm, pôdcse verificar que o vulcanismo existente sob a forma de montes submarinos c lineamentos oceânicos, ao longo das Zonas de Fratura de Ascensão c Bode Verde, tem marcante relação cronológica com eventos magmáticos observados na bacia occânica c na borda continental nos últimos $80 \mathrm{~m}$.a.. Esta relação se faz presente sob forma de reativações magmáticas, provavelmente devido à cxistência de zonas de fraquezas ligadas as zonas de fraturas occânicas c/ou aos estresses causados pela mudança na dirç̧ão da cxpansão
occânica. Palavras-chave: Magnetoestratigrafia; Crosta occânica; Zonas de fratura; lixpansão oceânica;
Magmatismo.

MAGNETOSTRATIGRAPHY OF THE OCEANIC CRUST BETWEEN THE ASCENSION AND BODE VERDE FRACTURE ZONES - $A$ systematic analysis of the marine magnetic anomalies along the Ascension lracture Zone (AF\%) and Bode Verde Fracture Zone (BVFZ), aiming to establish the magnetostratigraphy of this portion of the South American Plate and to understand the major tectonic events that occurred in the oceanic basin and continental margin. The magnetostratigraphy allowed to recognize an average spreading rate of $2.3 \mathrm{~cm} / y \mathrm{r}$ for the South American Plate during the last $80 \mathrm{~m} . y$, and also some periods of high spreading rate $(3.3 \mathrm{~cm} / \mathrm{yr})$ mainly in the early Cretaceous and Eocene. Particularly, such periods of high oceanic spreading rates are correlatable with changes in the strike of that fracture zones and with an increase of magmatism in the oceanic basin and continental margin. It is also noted that an increase in the offset of the fracture zones is correlated with periods of high spreading rates. It is concluded that most of the volcanism that built the seamounts and oceanic lineaments along the $A F Z$ and $B V F Z$ are chronologically related to the northeastern continental margin magmatic events in the late $80 \mathrm{my}$. The majority of the volcanic events in the ocean basin and continental margin seems to be due to magmatic reactivations related to increases in the oceanic spreading rates and to changes in the strike of the fracture zones.

Key words: Magnetostratigraphy; Oceanic crust; Fracture zones; Sea-floor spreading; Magmatism.

${ }^{1}$ Departamento de Geologia / L.AGEMAR-UFF Avenida Litorânea S/N - Prédio de Geociências - 4 andar Gragoatá - Nitcrói, RJ. 24210-340 lone/Fax: 719-4241

\footnotetext{
${ }^{2}$ Departamento de Geologia / LAGEMAR-UFF (Convênio PADCT/FINEP)

Doutorando do Observatório Nacional - CNPq (Atualmente no Lamont Doherty Earth Observatory of Columbia University, Programa Doutorado Sandwich CNPq-1995)
} 